\title{
ПОХОДЖЕННЯ ТРОЇЦЬКОГО ЗВИЧАЮ «ЗАВИВАННЯ БЕРІЗКИ» В УКРАЇНІ (КУЛЬТУРНО-ІСТОРИЧНА ПРОБЛЕМА)
}

Анотація: У науковій розвідиі наголошуємо, що свято під назвою «Семик» $i$ звичай «завивання берізки» у минулому однозначно мали відношення до Зелених свят і були невід'ємними складовими троӥцької обрядовості українців. Звертаємо увагу на поодинокість історикоетнографічних даних про відповідні явища духовної культури та порівняно незначну територію їх поширення (переважно окремі східні терени України). Враховуючи иі факти та значну популярність звичаю завивати берізку серед росіян $i$ меншою мірою серед білорусів, підтверджуємо варіант його немісцевого походження.

На основі аналізу фактичних матеріалів наголошуємо, що обряди, які виконували довкола ритуального деревия, мали чітку практично ідентичну послідовність у всіх східних слов'я. Відмінним було лише те, що обрядові дї з берізкою у росіян і білорусів зазвичай не обмежувалися ї̈ завиванням. Дерево зрубували, прикрашали стрічками, хустками та ходили з ним по селі або у гості до учаснищь обряду. На завершення його «роздягали» або розривали та кидали у воду. Своєю чергою, цей факт наштовхує на припущення про подібність українського купальського деревия $i$ російської тройцької берізки та ймовірність їх спільного генетичного походження.

Ключові слова: Зелені свята, «Семик», обрядові дії, завивання берізки, кумування

У традиційній духовній культурі українців важливе місце посідають Зелені свята, які попри негативний вплив глобалізаційних процесів залишаються важливим комплексом своєрідних вірувань і багатим пластом давніх народних звичаїв. Неодноразово обєктами наших досліджень були звичай клечати житлові та господарські будівлі троїцькою зеленню та звичай замаювати худобу напередодні Трійці. Окрему увагу приділено також традиційним рільничим і поминальним обрядам, які приурочувалися до зелено-троїцького періоду. Не оминули також метеорологічну тематику Зелених свят та ї̈ тісний зв'язок із віруваннями про душі покійників та їх тимчасове перебування на землі.

Серед обрядово-звичаєвого комплексу Зелених свят, на нашу думку, неоднозначне місце займають дії, пов'язані із завиванням берізки. 3 наявних історико-етнографічних джерел очевидно, що цей обряд приурочувався зазвичай до так званого «Семика», який вживався на означення четверга перед Трійцею або ж Зеленої неділі. Важливість даної розвідки не потребує спеціальних аргументацій, позаяк досі тривають дискусії вченихгуманітаріїв стосовно феномену завивання берізки, особливо походження цього звичаю та його змісту. Нерозв'язаність даної проблеми певною мірою зумовлена локальністю його поширення і тим фактом, що більшість дослідників троїцької календарної обрядовості

\footnotetext{
"Пахолок Інна Ростиславівна - кандидат історичних наук, старший викладач Відокремленого підрозділу «Львівська філія Київського національного університету культури і мистецтв» (Львів, Україна); ORCID: https://orcid.org/0000-0001-9929-8166; e-mail: paholok.inna@ukr.net
} 
Зелених свят спеціально не зупинялися на аналізі цього культурного явища, а розглядали лише побіжно, у контексті своїх зацікавлень. Відтак, метою розвідки є науково обгрунтована характеристика українського варіанту звичаю «завивання берізки» та спроба реконструкції втрачених компонентів і новий погляд стосовно його смислового наповнення. Методологія дослідження грунтується на принципах історизму, обєєтивності та комплексності. Відповідно до теми дослідження застосовуємо методи історичної дедукції і реконструкції, типологічного та порівняльно-історичного аналізу.

Загальновідомо, що сьогодні у різних куточках України Зелені свята святкують переважно три дні, хоча в минулому готувалися до цього свята заздалегідь - за тиждень, який називали «зеленим». Тому цілком закономірним є те, що ще донедавна селяни пам'ятали про Зелену п'ятницю чи суботу, які, власне, передують Трійці. Крім зеленого тижня, українці, передовсім поліщуки, досить часто згадують про русальний тиждень, який, за одними свідченнями, відзначається перед Трійцею, за іншими - після свят. Те ж саме стосується клечального тижня. Для уникнення плутанини тиждень перед Зеленими святами називаємо клечальним, а тиждень після свят русальним (троїцьким).

Потрібно відзначити, що аналогічної структури Зелених свят у минулому дотримувалися сусідні слов'янські етноси. Скажімо, білоруси Трійцю святкували також три дні, але «увесь Семушний тиждень називали Клечальним і нічого не робили». У контексті сказаного лише відзначимо, що «Сёмуха» або «Семік» - інші назви Зелених свят у білорусів 2 Натомість росіяни Семиком означували не Зелені свята, а четвер перед Трійцею, про що довідуємось із докладних описів російських етнографів В. Проппа і В. Соколової․

Стосовно теренів України, то тут слово «Семик» майже не побутувало. 3 огляду на цей факт можна цілком погодитися 3 думкою М. Максимовича, який наголошував, що «четвер, під назвою Семик відомий лише у пн. [північній] Русі, а на Україні він невідомий» ${ }^{4}$ Про нього згадував С. Килимник, але обгрунтованих висновків щодо походження слова та його вживання дослідник не подав ${ }^{5}$.

Загалом, усі ці розбіжності українських і зарубіжних дослідників дають підстави сумніватися у тому, що Семик був одним із структурних компонентів Зелених свят українців. Те ж саме стосується звичаю завивання дівчатами берізок, який у більшості випадків має пряме відношення до святкування Семика. Правдоподібність цього припущення цілком можлива, зважаючи на скупість і неточність інформації стосовно відповідного дня (свята), яка міститься у джерелах і науковій літературі. Вочевидь,

\footnotetext{
${ }^{1}$ Земляробчы календар: абрады і звычаі / Уклад., класіф., сістэм. матэриаялау і камент А.І. Гурскага; уступ. арт. А.І. Гурскага, А.С. Ліса. Мінск: Наука і тэхніка, 1990. С. 51.

${ }^{2}$ Шейн П.В. Материалы для изучения быта и языка русского населения Северо-западного края. СанктПетербург, 1897. Т. І.Ч.І. С. 184; Крачковский Ю.Ф.ББыт Западно-Русского селянина. Москва: Издание Императорского Общества истории и древностей российских при Московском Университете. 1874. Кн. 4. C. 120 .

${ }^{3}$ Пропп В.Я. Русские аграрные праздники: (Опыт историко-этнографического исследования). Ленинград: Ленинградский гос. ун-т им. А.А. Жданова. 1963. С. 58; Соколова В.К. Весенне-летние календарные обряды русских, украинщев и белоруссов XIX-XX в. Москва: Наука, 1979. С. 188.

${ }^{4}$ МаксимовичМ. Дні та місяці українського селянина / упоряд., перек. 3 рос., вступ. стаття та прим. В. Гнатюка. Київ: Обереги, 2002. С. 64.

${ }^{5}$ Докладніше див.: Килимник $C$. Український рік у народних звичаях в історичному освітленні. Київ: АТ «Обереги», 1994. Кн. II. Т. 3-4. С. 368.
} 
небезпідставно О. Воропай наголошував на тому, що переважно у східних історикоетнографічних районах «довго зберігався звичай завивати берізку» ${ }^{6}$. Крім цього, автор подав його докладний опис, який свого часу зафіксував Терещенко у с. Березівка на Саратовщині ${ }^{7}$

Дуже промовистим у цьому сенсі є слушне спостереження В. Соколової, що завивати берізку ходили переважно у четвер й обряд цей був пов'язаний із Семиком. Позаяк його переставали святкувати, то де-не-де берізку почали завивати перед Трійцею або на Трійцю, відповідно тоді ж їі і розвивали ${ }^{8}$ Доцільно наголосити й на іншому моменті: троїцька берізка у росіян дуже схожа на купальське деревце (марену) в українців. Йдеться не лише про зовнішній вигляд ритуальних дерев, а й про дії, які відбувалися довкола них. Це дало підстави для російських дослідників вважати, що українці, в яких Трійця не стала таким важливим святом, як у росіян, один з найважливіших елементів семицько-троїцької обрядовості перенесли на Купалу․

Припускаємо, що висловлене припущення є не зовсім переконливим, позаяк наші сусіди протягом троїцького періоду виконували багато елементів купальської обрядовості, яка, до речі, значно колоритніша в українців. Маємо на увазі передовсім обрядове деревце, плетіння та пускання вінків, так зване кумування. До речі, останній обряд побутував у багатьох європейських народів, але він приурочувався переважно до Івана Купала, i кумувалися між собою жінки та чоловіки. На цьому моменті наголошуємо спеціально, позаяк підтримуємо висновок, який свого часу зробив відомий російський дослідник Олександр Веселовський. Автор, розглянувши відповідний обряд у порівнянні з іншими обрядами, які населення виконувало на літнього Івана, констатував, що іванівське побратимство та кумування є відгуком давнього обряду прийняття у рід і родового свята укладання шлюбів. Більше того, вчений був переконаний у тому, що у росіян обряд кумування, як і деякі інші обряди, з Іванового дня були перенесені на Трійцю10.

Так чи інакше, але у четвер перед Зеленими святами місцеві дівчата із досвітку пекли пироги, різні солодощі, готували яєчню. У дворі будь-якої з них ставили зрубане молоде деревце, а під ним - горщик із водою. у полудень одна з дівчат відділялася від гурту, підходила до дерева та перекидала горщик, а потім брала дерево в руки і заспівувала пісню. Увесь гурт, оточивши дівчину з деревом, рухався по вулиці у напрямку лісу, де по закінченню гостини вибирав одну з берізок, на якій завивали вінки. Якщо дівчат було багато, то вибирали декілька берізок такої величини, щоб можна було дістати гілля, стоячи під деревом. Розділившись по двоє, кожна пара з гілля берізки сплітала собі один вінок, не відриваючи гілок від дерева. Якщо вінок був готовий, кожна пара дівчат кумувалася: одна одній давала через вінок жовту крашанку. Обмінявшись крашанками, вони цілувалися через вінок ${ }^{11}$.

Зрозуміло, що відносини кумівства були недовгими і завершувалися через кілька днів (тиждень або півтори) діями, які були протилежними під час завивання берізки та

\footnotetext{
${ }^{6}$ Воропай О. Звичаї нашого народу: Етнографічний нарис. Мюнхен: Українське видавництво, 1966. Т. 2. С. 146.

${ }^{7}$ Терещенко А. Быт русскаго народа. Санкт-Петербург: Тип. военно-учебных заведений, 1848. Ч. VI. С. 167.

${ }^{8}$ Соколова В.К. Весенне-летние календарные обряды русских, украинцев и белоруссов XIX-XX в. С. 190.

${ }^{9}$ Ibid. C. 196.

${ }^{10}$ Веселовский А.Н. Гетеризм, побратимство и кумовство в купальской обрядности (Хронологичиские гипотезы) // Журнал Министерства народного просвещения. 1894. № 2. С. 316-318.

${ }^{11}$ Воропай О. Звичаї нашого народу... С. 146-147.
} 
кумування. Після завивання вінків дівчата поверталися у село. У неділю вони йшли у той самий ліс, де завивали вінки, щоб знову їх розвити. Кожна пара дівчат оглядала свій вінок: чи ще свіжий, чи вже зів'яв. По цьому судили про своє щастя чи нещастя, а також ворожили про довговічність батьків, сестер, братів і наречених. Ворожіння відбувалось під час розвивання вінків: якщо вінок не засохнув, то дівчина буде довго жити. Зів'ялі вінки кидали у воду: як попливе - на щастя, потоне - на біду.

Аналогічний звичай відомий у минулому також білорусам, що засвідчує одна із «семушних» пісень:

Пойдзем, дзеванькі, мыс уц гай гулящь,

Да вянкі зауём, да на ўсе святкі,

На духаўскія, на пятроуивскія.

Ой, што дух-тройца - то ізбор дзеўкам.

Ай, не радуйся, зелёны дуб,

Не к табе ідзём вянкі віць,

Ай, узрадуйся, бяроза белая,

Мык табе ідзём вянкі завіваць ${ }^{12}$.

На Смоленщині обряд завивання берізки теж супроводжувався піснеспівами:

Близ тебя, березонька,

красные девушки

В Семик поют.

Под тобой, березонька,

Красны девушки

Венки плетут ${ }^{13}$

До речі, українські дослідники, у працях яких також містяться згадки про завивання берези, переважно стверджують, що цю обрядову дію виконували в неділю. Скажімо, С. Килимник наголошував на тому, що переважно вранці у Зелену неділю дівчата беруть із собою різні харчі, закликають хлопців і, співаючи веснянки та гаївки, прямують до лісу. Тут проводяться ігри, співи, хороводи й неодмінно частуються. Переважно сідають за їжу колом у перемішку, тобто хлопець - дівчина. Після гостини хлопці збираються окремо, співають і жартують 3 дівчатами. Натомість останні вибирають 3 довгим і тонким гіллям берізку (молоде й непошкоджене деревце), на якій завивають вінки, виконуючи відповідні пісні:

По саду ходжу, виноград саджу,

Посадивши та й поливаю,

Ой поливши та й нащіпаю,

Нащіпавши, віночка зівю,

Віночка звивши на воду пущу.

Хто вінка пійме, той мене візьме... ${ }^{14}$.

\footnotetext{
${ }^{12}$ Ліцьвінка В.Д. Святы і абрады беларусаў / ред. Л.М. Раменьчык. Минск: Бєларусь, 2001. С. 102.

${ }^{13}$ Романова О. Культ берізки в Семицько-Троїцьких обрядах східних слов'ян // Наукові записки Кіровоградського державного педагогічного університету імені Володимира Винниченка. Серія: Історичні науки. 2014. Вип. 19. С. 54.

${ }^{14}$ Килимник C. Український рік у народних звичаях в історичному освітленні... С. 364-365.
} 
Дещо іншу пісню, яка супроводжувала виття вінків, у середині ХІХ ст. зафіксував П. Чубинський. Зокрема, вона містила такі рядки:

Ой завю вінки та на всі святки,

Ой на всі святки, на всі празники,

Да рано, рано на всі празники... ${ }^{15}$.

Завивши вінки, хлопці іх обережно відламували, щоб не розвинути, і доручали дівчатам. Останні несли ці вінки з піснями до дому, а ввечері йшли до водойми і пускали їх на воду.

у порівняльному плані не менше зацікавлення становить інформація, яку подав у своїй розвідці М. Дикарєв. Зокрема, автор зазначив: «На Сьвяту неділю дівчата посходяться під церкву та й плетуть гуртом вінки: великі дівчата собі, а маленькі собі [...]. Тоді як сплетуть, несуть до дому до якої-небудь дівчини, загорнуть у платок його, щоб не поламав. Тоді розходять ся, пообідають та поять посходяться де-небудь у садок куматься. Повісять вінок на вишню, тоді хрест повісять на вінок, такий, що на шиї носять, тоді ото крізь вінок хрест цілують, намистом міняються, платками до Петрового дня. Ті, що поміняють ся, кумами звуться. А вінок дівчата беруть і ховають: миють 3 їм голову, щоб волосся росло» ${ }^{16}$. Оскільки у росіян кумування було популярним у більшості областей, то й асортимент речей, якими обмінювалися, був значно ширшим. Крім яєць наші сусіди обмінювалися одягом, хрестами, хустинами, вінками, перснями, бусами, коржами ${ }^{17}$.

У контексті сказаного варто з'ясувати також, чому серед усіх дерев саме берізка була об’єктом завивання та кумування молоді. Як відомо, у багатьох східнослов'янських баладах, легендах, казках дівчина, яка отруїлася або втопилася, перетворюється у березу: березовий стовбур називається тілом дівчини-потопельниці, а листя - її волоссям ${ }^{18}$. На Україні цю категорію дівчат, які померли у такий спосіб, прийнято називати русалками.

Дуже промовистими у цьому сенсі є слова з української пісні:

Не рубай, братику, білої березоньки,

Не коси, братику, шовкової трави.

Не зривай, братику, чорного терну:

Білая березонька - то я молоденька,

Шовковая трава - то моя руса коса,

Чорній терен - то мої чорні оч $i^{19}$

3 огляду на це стає очевидно, чому саме на березі завивають вінки і чому саме в цей період, коли поминають цю категорію померлих. Це троїцьке деревце не лише

\footnotetext{
15 Чубинский П.П. Труды этнографическо-статистической экспедиции в Западно-Русский край, снаряженной Русским географическим обществом Юго-Западного отдела. Материалы и исследования. Санкт-Петербург, 1872. Т. 3: Народный дневник. С. 190.

${ }^{16}$ Дикарев М. Народний календар Валуйського повіту (Борисівської волости) у Вороніжчині // Матеріали до українсько-руської етнології. Львів, 1905. Т. 6. С. 185.

${ }^{17}$ Агапкина Т.А. Мифопоэтические основы славянского народного календаря: Весенне-летний цикл. Москва: Индрик, 2002. С. 484. [Традиционная духовная культура славян / Современные исследования].

${ }^{18}$ Усачева В.В. Магия слова и действия в народной культуре славян. Москва: Институт славяноведения РАН, 2008. C. 188.

${ }^{19}$ Цит. за: Усачева В.В. Магия слова и действия в народной культуре славян... С. 189.
} 
уособлювало русалок, а й згідно з народними уявленнями, було місцем їхнього тимчасового перебування на «тому світі» ${ }^{20} .3$ іншого боку зрозуміло, чому білоруські дівчата наголошували на тому, що вінки плели русалкам, щоб ті здобули їм женихів і чому після завивання дівчата обмінювалися між собою обручками ${ }^{21}$.

Отже, у дослідженні з'ясовано, що спорадичне згадування Семика на теренах України $€$ наслідком тривалого контакту нашого народу з сусідніми етносами, особливо на порубіжних територіях. Йдеться передовсім про білорусів і росіян. Це зауваження є слушним, позаяк саме у них Семик посідав важливе місце у троїцько-русальному циклі. Вірогідно, внаслідок тісних взаємовпливів українці швидше всього перейняли цю назву і включили її в обрядовість своїх Зелених свят. Мабуть, таким же шляхом потрапив на українські землі обряд «завивання берізки» і пов’язані з ним кумування та колективні дівочі пригощання.

На підставі скрупульозного аналізу історико-етнографічних матеріалів стверджуємо, що усі складові обряду по відношенню до берізки загалом у східних слов'ян були практично аналогічними та зберігали чітку хронологічну послідовність. Щоправда на теренах України обрядові дії з берізкою були часто скромнішими у порівнянні з нашими північними та східними сусідами й обмежувалися лише її завиванням. Зважаючи на схожість українського купальського деревця та російської троїцької берізки, припускаємо, що вони мають спільне коріння. Залишається відкритим питанням і полем для нового дослідження питання про те, яке ритуальне деревце почало використовуватися історично швидше і з якої обрядовості в яку (троїцька в купальську чи купальська в троїцьку) воно перейшло. І що стало ключовим поштовхом до цієї трансформації.

\title{
Inna Pakholok
}

\section{The Origin of the «Zavyvannia Berizky» Holy Trinity Custom in Ukraine (within cultural and historical aspect)}

\begin{abstract}
The «zavyvannia berizky» ancient rite of twisting and subsequent untwisting branch wreaths directly on a live birch tree takes an equivocal place in the structure of the Holy Trinity ritual traditions. Based on the available historical and ethnographic sources, it can be obviously concluded that this rite was usually timed to the so-called «Semyk», which fell on the last Thursdayof the Green Week (Whitsuntide week) or on the HolyTrinity Sunday. The purpose of the research is a scientifically substantiated description of the Ukrainian version of the "zavyvannia berizky» custom and the attempt to reconstruct the lost ritual components as well as as to present a new look at its semantic content. The research methodology is based on the principles of historicism, objectivity and comprehensiveness. According to the theme, the author applies the corresponding methods of historical deduction,

\footnotetext{
${ }^{20}$ Про зв'язок троїцької зелені та русалок див. детал.: Paholok I., Hrynokh N. Klechalny custom as a spiritual phenomenon of ukrainian culture // East European Historical Bulletin. 2020. Issue 17. P. 212-218. DOI: https://doi.org/10.24919/2519-058x.17.218198

${ }^{21}$ Романова О. Культ берізки в Семицько-Троїцьких обрядах східних слов'ян... С. 54.
} 
reconstruction, typological and comparative-historical analysis.

The study argues the opinion that in the past «Semyk» and the «zavyvannia berizky» rituals unambiguously existed among the Ukrainian population. Attention is drawn to just a few historical and ethnographic data on the corresponding phenomenon of spiritual culture and the relatively small territory of its distribution (mainly separate territories of eastern Ukraine). Considering these facts and the great popularity of the "zavyvannia berizky» custom among Russians and, to a lesser extent, among Belarusians, we confirm the option of its nonlocal origin. Based on the analysis of factual materials, it is emphasised that all Eastern Slavs had almost similar components and sequence of performing that rite. The only difference was that the ritual actions with a birch tree among Russians and Belarusians were usually not limited to its branch wreathes twisting. The tree was cut down, decorated with ribbons, scarves, and peasants walked with it around the village or paid visits to the participants of the ceremony. Finally, it was «undressed» or untwisted and thrown into the water. In turn, this fact prompts an assumption about the similarity of the Ukrainian Kupala Night tree and the Russian Trinity birch tree, and the probability of their joint genetic origin.

Keywords: Green week (Whitsuntide week), «Semyk», rites, zavyvannia berizky, kumuvannia 